Beagle. He certainly was bitten by the vector of Chagas's disease, but there is no certainty that they were infected. The infection can cause myocardial damage and heart failure, megacolon and megaoesophagus, but it is often asymptomatic.

Evidence from Darwin's writings and those of some of his relatives indicates that his symptoms were of palpitations, lassitude, headaches, tremulousness, sleeplessness, and flatulence brought on by meeting people and by emotionally charged situations. His exercise tolerance remained good until shortly before his death at the age of 73 .

Though attended by some of the best clinical observers of the day no signs of disease were detected. Persons may die with asymptomatic Chagas's disease, but it is considered to be beyond credibility that severe incapacity could have been produced by it for 40-50 years without the development of physical signs.

There is evidence that several of Darwin's children who were not exposed to infection with Chagas's disease nevertheless had a disease similar to their father's.

The course of the illness was unlike that of an organic disorder causing cardiac insufficiency in that the symptoms improved during the last decade of his life. The features of the illness strongly suggest a diagnosis of a functional disorder.
Perhaps the most important piece of evidence is that the principal symptoms developed before Darwin sailed for South America.

\section{REPERENCES}

Adler, S. (1959). Nature (Lond.), 184, 1102.

Barlow, N. (1958). Autobiography of Charles Darwin 1809-1882, edited by Norah Barlow. Collins, London.

Brain, W. R. (1949). Brit. med. Y., 2, 1427.

Coll, J. A. (1940). An. Med publ., 2, 69.

Darwin, C. (1906). Journal of Researches into the Geology and Natural History of the Various Countries visited during the Voyage of H.M.S Beagle round the world, p. 316 . Everyman's Library. Dent, London.

Darwin, F. (1958). Autobiography of Charles Darwin and Selected Letters, edited by Francis Darwin. Constable, London.

Greenacre, P. (1963). I he Quest for the Father, p. 28. International University Press, New York.

Hubble, D. (1943). Lancet, 1, 129

Kempf, E. J. (1921). Psychopathology, p. 208. Kimpton, London. Litchfield, H. (1915). Emma Darwin: A Century of Family Letters, 1792-1896, edited by Henrietta Litchfield, 2, 104. Murray, London.

Mazza, S. Miyara S. Basso, G., and Basso, Y. R. (1941). Primer quincuenio de la investigación por la M.E.P.R.A. de en Enfermedad de Chagas en la provincia de Mendoza. Imprenta Oficial, Mendoza, Argentina.

Neghme, R. A. and Schenone, F. H. (1962). Anais de Congresso Internacional sôbre a Doença de Chagas, 3, 1069.

Raverat, G. M. (1960). Period Piece: A Cambridge Childhood. Faber and Faber Ltd, London.

Stecher, R. M. (1961). Ann. Sct., Vol. 17.

\title{
Creatine Kinase Levels in Women who Carry Genes for Three Types of Muscular Dystrophy
}

\author{
K. M. WILSON,* B.SC.; K. A. EVANS, † A.M.I.A. ; C. O. CARTER, $\dagger$ B.M., F.R.C.P.
}

Brit. med. F., 1965, 1, 750-753

Severe sex-linked muscular dystrophy is a condition for which it would be most valuable to have a reliable test to identify carrier women. A young woman who has seen two brothers die of the disease is naturally anxious to know the risk that she may have affected sons; one in two such women are not carriers and if identifiable could be reassured. Probably one in three women who have one son with the disease but no other affected male relative do not carry the gene, and, if identifiable, could be reassured that they were unlikely to have a second affected son or a carrier daughter.

Claims that the level of serum aldolase is helpful in the detection of carrier women (Schapira et al., 1960; Chung et al., 1960 ; Hughes, 1962a) have, unfortunately, not been confirmed (Leyburn et al., 1961 ; Clayton et al., 1963). However, Schapira et al. (1960) also reported high levels of creatine kinase (adenosine triphosphate creatine phosphotransferase) in 8 out of 19 carriers of the gene for severe sex-linked muscular dystrophy. This enzyme is found only in muscle and nerve tissue and so high levels are not produced by red-cell haemolysis in vitro or by liver disease, both of which result in a raised level of serum aldolase. Aebi et al. (1961-2) in Switzerland, and Hughes (1962a) reported more encouraging results with creatine kinase. Hughes found that six out of seven women known to carry the gene for severe sex-linked muscular dystrophy had raised levels, and the Swiss workers (Richterich et al., 1963) also found that six out of seven known carriers had high levels. More recently Pearce et al. (1964b) found

\footnotetext{
- Department of Chemical Pathology, the Hospital for Sick Children, Great Ormond Street. London

† Medical Research Council's Clinical Genetics Research Unit, Institute of Child Health, Great Ormond Street, London.
}

that five out of seven known carriers and 17 out of 35 possible carriers had high levels by their standards.

We now report a series which indicates that, taking the mean of three separate estimations, about $90 \%$ of heterozygotes for the gene for the severe sex-linked form have an enzyme level higher than that reached by all but $10 \%$ of controls ; also that a substantial proportion of heterozygotes for the mild (Becker) type of sex-linked dystrophy may be detected.

\section{Method}

The reaction-creatine phosphate $+\mathrm{ADP} \rightleftharpoons$ creatine $+\mathrm{ATP}$ -is a linear function of creatine kinase activity except for serum in which the level of creatine kinase is very high (above about 14 units). The forward reaction proceeds 10 times faster than the backward, and so methods using it are to be preferred. The creatine formed by the forward reaction was estimated by Hughes's (1962b) modification of the method of Dreyfus and Schapira (1961) on serum from capillary blood. There was no significant difference in levels of the enzyme in serum and plasma, but the latter was apt to deposit fibrin clots on deep freezing. All results are expressed in units which are $\mu \mathrm{M}$ creatine per $\mathrm{ml}$. serum per hour at $37^{\circ} \mathrm{C}$; t the conversion factor to " international units" is 16.67 .

The serum creatine kinase levels were found to be unaffected by deep freezing or by standing at room temperature for 24 hours. Specimens were stored at $-25^{\circ} \mathrm{C}$. and the enzyme level was estimated within six weeks of collection, as Hughes (1962b) observed a decrease in activity after eight weeks' storage. A significant decrease in enzyme activity was found 
in grossly haemolysed serum, presumably due to dilution of the enzyme by the contents of red blood cells, and such specimens should not be used.

\section{Natural Variation in Creatine Kinase Level in Females}

Variation in Single Individuals.-Pearce et al. (1964a) found no variation in enzyme levels after the ingestion of a heavy meal, or with menstruation, or with pregnancy, or after moderate exercise. We, too, found no variation with menstruation or moderate exercise, and no variation with the time of day at which the specimen was collected. The variations found in individual women on different days (at intervals ranging from a week to four months) may be seen in Tables III, IV, V, and VI. The effect of moderate exercise (a brisk four-mile $(6.5-\mathrm{km}$.) walk) was tested on eight subjects, and the absence of any significant increase is shown in Table I. Severe or prolonged exercise can cause a marked rise in enzyme level (Richterich et al., 1963 ; Griffiths, personal communication).

TABLE I.-Effect of Moderate Exercise on Creatine Phosphokinase

\begin{tabular}{|c|c|c|c|c|}
\hline $\begin{array}{l}\text { Normal } \\
\text { Adult }\end{array}$ & $\begin{array}{l}\text { Immediately } \\
\text { Before Walk }\end{array}$ & $\begin{array}{l}\text { Immediately } \\
\text { After Walk }\end{array}$ & $\begin{array}{l}30 \text { minutes } \\
\text { After } W \text { alk }\end{array}$ & $\begin{array}{l}1 \text { Hour } \\
\text { After Walk }\end{array}$ \\
\hline Female & $\begin{array}{l}0.9 \\
1.1 \\
1.3 \\
1.4 \\
1.9\end{array}$ & $\begin{array}{l}1.1 \\
1.2 \\
1.3 \\
1.3 \\
1.9\end{array}$ & $\begin{array}{l}1.0 \\
1.0 \\
1.5 \\
1.6 \\
1.9\end{array}$ & $\begin{array}{l}1 \cdot 0 \\
1.2 \\
1.3 \\
1.5 \\
1.9\end{array}$ \\
\hline$\cdots\{$ & $\begin{array}{l}0.9 \\
1.4 \\
1 \cdot 1\end{array}$ & $\begin{array}{l}0.9 \\
1.3 \\
1.0\end{array}$ & $\begin{array}{l}1.0 \\
1.4 \\
1.3\end{array}$ & $\begin{array}{l}1.0 \\
1.3 \\
0.9\end{array}$ \\
\hline Mean .. & 1.25 & 1.25 & 1.34 & $1 \cdot 26$ \\
\hline
\end{tabular}

Variation with Age of Subjects.-Griffiths (1964) found no difference between the levels in adults and children, though the level was raised in the neonatal period. We, too, found no significant difference between the levels in girls and adult women, nor, within the adult group, between young, middleaged, and elderly women. The mean enzyme levels on a single specimen in 15 girls aged $1-15$, in 39 women aged 18-29, in 12 women aged $30-59$, and 10 women aged over 60 are shown in Table II ; none of them had a relative affected by muscular dystrophy.

TABLE II.-Serum Creatine Kinase Activity in Female Controls

\begin{tabular}{c|c|c}
\hline Age-group (Years) & No. of Females & $\begin{array}{c}\text { Mean Serum Creatine Kinase } \\
(\mu \mathrm{M} \text { Creatine/ml. Serum/hr. } \\
\left.\text { at } 37^{\circ} \mathrm{C} .\right)\end{array}$ \\
\hline $1-15$ & 15 & $1 \cdot 49$ \\
\hline $18-29$ & 39 & $1 \cdot 27$ \\
$30-59$ & 12 & $1 \cdot 21$ \\
$60+$ & 10 & $1 \cdot 45$ \\
\hline $18-60+$ & 61 & 1.31 \\
\hline
\end{tabular}

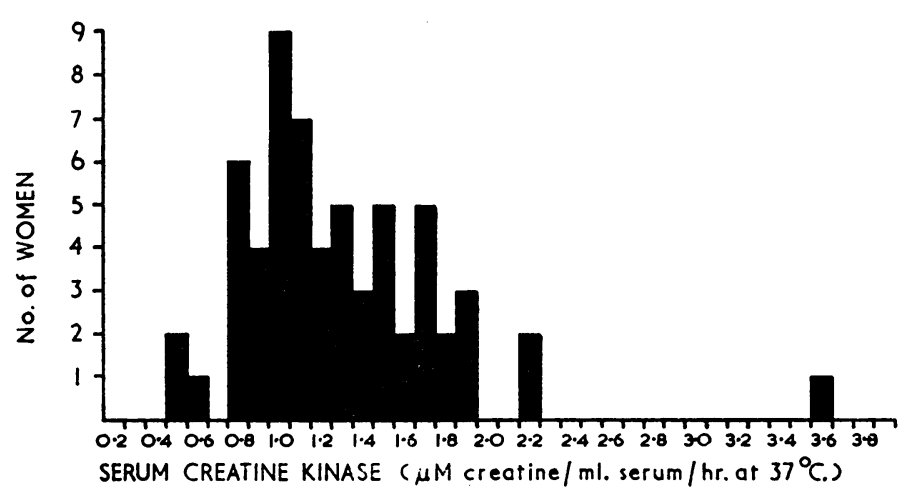

FIG. 1.-Distribution of serum creatine kinase levels in a first specimen for 61 women over 18 years of age.
The distribution of levels in a first single specimen for the 61 women aged 18 and over is shown in Fig. 1. The lowest value found was 0.5 , the highest 3.6, and the next highest 2.2 . The value of 3.6 was exceptional, but this woman gave values of 1.8 and 2.5 on other days. The mean level was 1.29 and the standard deviation 0.50 . The distribution was not normal, but was skewed to the right. The logarithms of the levels have a more normal distribution. The theoretical range of 0.59 to 2.48 units estimated from the mean, 0.083 (1.21 units), and standard deviation, 0.056 , of the logarithms of the enzyme levels was more realistic than the range 0.29 to 2.29 calculated from the actual levels.

\section{Comparison of Creatine Kinase Levels in Women Heterozygous for Genes for Muscular Dystrophy and Controls}

Comparison of control women and those known to be heterozygous for genes for muscular dystrophy was made on three specimens, collected on different days, from each woman so as to minimize the effect of daily variations.

The findings in 21 control adult women are shown in Table III and Fig. 2 (the first specimens from these women are included in the 61 single estimations reported above). The range of the mean of three values was from 0.8 to 2.6 units

TABLE III.-Serum Creatine Kinase Activity in Three Specimens Collected on Different Days in 21 Control Pemales Aged 2-49 Years

\begin{tabular}{l|c|c|c|c|c|c|c}
\multicolumn{2}{c}{ Serum } & Creatine Kinase Activity $\left(\mu \mathrm{m}\right.$. Creatine/ml. Serum/hr. at $37^{\circ}$ C.) \\
\hline 1st & 2nd & 3rd & Mean & 1st & 2nd & 3rd & Mean \\
\hline 1.1 & 1.1 & 1.0 & 1.06 & 1.2 & 0.8 & 1.5 & 1.16 \\
1.0 & 1.1 & 1.1 & 1.07 & 1.2 & 1.1 & 0.8 & 1.03 \\
1.0 & 1.1 & 0.8 & 0.97 & 1.7 & 1.5 & 2.1 & 1.77 \\
1.0 & 0.9 & 0.9 & 0.93 & 1.3 & 1.5 & 1.2 & 1.33 \\
1.1 & 1.6 & 1.9 & 1.53 & 1.8 & 1.8 & 1.9 & 1.83 \\
1.0 & 1.3 & 1.3 & 1.20 & 3.6 & 1.8 & 2.5 & 2.63 \\
0.9 & 1.3 & 1.2 & 1.13 & 1.5 & 1.9 & 1.6 & 1.67 \\
1.9 & 1.1 & 0.8 & 1.27 & 1.2 & 1.5 & 0.9 & 1.20 \\
0.8 & 0.8 & 1.1 & 0.90 & 1.6 & 1.9 & 2.0 & 1.83 \\
1.5 & 1.3 & 1.4 & 1.40 & 0.9 & 0.9 & 1.3 & 1.03 \\
0.7 & 0.9 & 0.8 & 0.80 & & & & \\
\end{tabular}

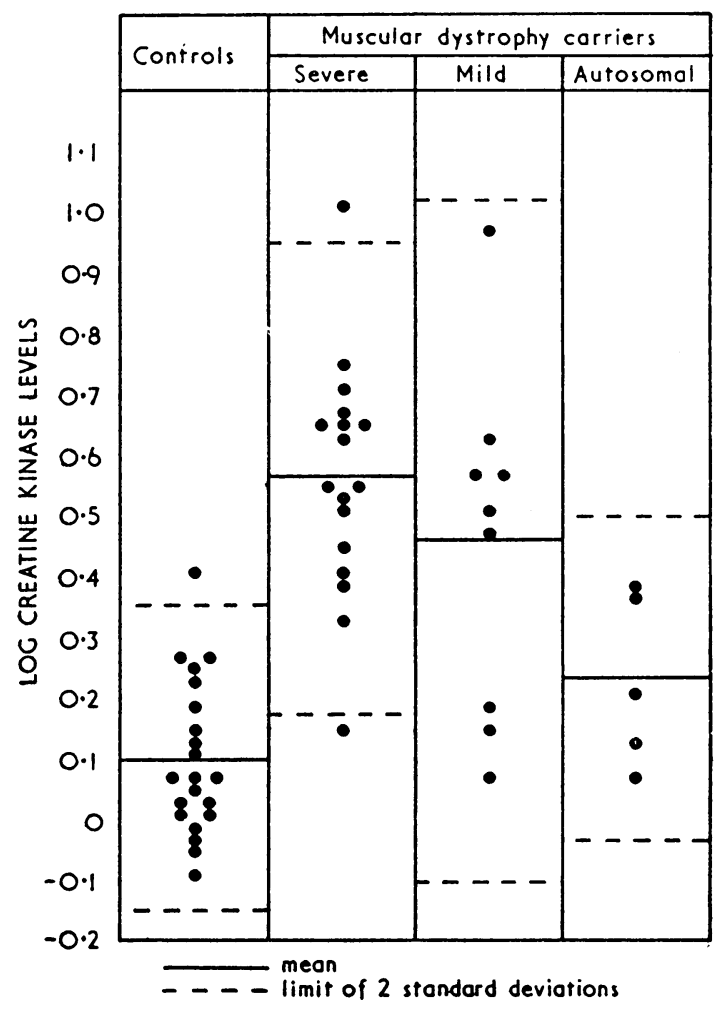

FIG. 2.- Log creatine kinase levels (mean of three specimens) in controls and heterozygotes. 
with an sverall mean of 1.31 and standard deviations 0.44 ; using logarithms, the mean was 0.102 (1.26 units), and standard Jeviation 0.127 , giving a range of 0.70 to 2.27 units.

The findings in 17 women, all adults, known to be heterozygous for the gene for severe sex-linked muscular Jystrophy are shown in Table IV and Fig. 2. The evidence that these women are heterozygotes is given in the right-hand column of Table IV and in Fig. 3. The range of the mean of three values was from 1.4 to 10.5 , with an overall mean of 4.02 and standard deviation 2.01 ; using logarithms, the mean was 0.563 (3.65 units) and standard deviation 0.194, giving a range of 1.50 to 8.93 units. As with the control women, age Jid not appear to influence the enzyme level.

The findings in nine females (seven adults and two girls) heterozygous for the gene for mild sex-linked muscular

TABLE IV.-Serum Creatine Kinase Activity in Women Known to be Heternzygous for the Gene for Severe Sex-linked Muscular Dystrophy

\begin{tabular}{|c|c|c|c|c|c|}
\hline \multirow{2}{*}{ Pamilies } & \multicolumn{4}{|c|}{$\begin{array}{l}\text { Serum Creatine Kinase Activity }(\mu \mathrm{M} \\
\left.\text { Creatine } / \mathrm{ml} \text {. Serum } / \mathrm{hr} \text {. at } 37^{\circ} \text { C. }\right)\end{array}$} & \multirow{2}{*}{$\begin{array}{l}\text { Affected Relatives } \\
\text { of Heterozygous Women }\end{array}$} \\
\hline & 1 st & 2nd & 3 rd & Mean & \\
\hline$A\left\{\begin{array}{l}\mathbf{I}_{1} \\
\mathbf{I}_{2} \\
\mathbf{I}_{8} \\
\mathbf{I}_{5} \\
\mathbf{I I}_{6}\end{array}\right.$ & $\begin{array}{l}3.5 \\
2 \cdot 6 \\
3 \cdot 6 \\
1.9 \\
5 \cdot 1\end{array}$ & $\begin{array}{l}3.6 \\
2 \cdot 3 \\
2 \cdot 3 \\
6.0 \\
4.9\end{array}$ & $\begin{array}{l}6 \cdot 4 \\
2 \cdot 7 \\
4 \cdot 6 \\
4 \cdot 7 \\
5 \cdot 7\end{array}$ & $\begin{array}{l}4 \cdot 50 \\
2 \cdot 53 \\
3 \cdot 50 \\
4 \cdot 20 \\
5 \cdot 23\end{array}$ & Sec pedigree A \\
\hline B $\left\{\begin{array}{l}\mathrm{II}_{1} \\
\mathrm{III}_{:}\end{array}\right.$ & $\begin{array}{l}4 \cdot 4 \\
3 \cdot 5\end{array}$ & $\begin{array}{l}2 \cdot 6 \\
2 \cdot 2\end{array}$ & $\begin{array}{l}3.0 \\
1.6\end{array}$ & $\begin{array}{l}3 \cdot 33 \\
2 \cdot 43\end{array}$ & \} See pedigree $B$ \\
\hline 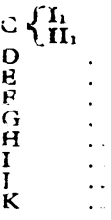 & \begin{tabular}{r|}
$2 \cdot 8$ \\
$1 \cdot 8$ \\
$4 \cdot 1$ \\
$4 \cdot 0$ \\
$10 \cdot 2$ \\
$3 \cdot 3$ \\
$1 \cdot 8$ \\
$4 \cdot 3$ \\
$5 \cdot 1$ \\
$4 \cdot 2$
\end{tabular} & $\begin{array}{r}2 \cdot 1 \\
1 \cdot 3 \\
3 \cdot 3 \\
5 \cdot 7 \\
11 \cdot 9 \\
4 \cdot 2 \\
2 \cdot 1 \\
2 \cdot 8 \\
4 \cdot 7 \\
4.5\end{array}$ & $\begin{array}{l}3 \cdot 5 \\
1 \cdot 2 \\
3 \cdot 4 \\
4 \cdot 2 \\
9 \cdot 3 \\
5 \cdot 8 \\
2 \cdot 5 \\
2 \cdot 5 \\
6 \cdot 9 \\
4 \cdot 6\end{array}$ & $\begin{array}{r}2 \cdot 80 \\
1 \cdot 43 \\
3 \cdot 60 \\
4 \cdot 63 \\
10 \cdot 47 \\
4 \cdot 43 \\
2 \cdot 13 \\
3 \cdot 20 \\
5 \cdot 57 \\
4 \cdot 43\end{array}$ & $\begin{array}{l}\text { See pedigree C } \\
2 \text { sons } \\
1 \text { son, } 1 \text { sister's son } \\
2 \text { sons } \\
2 \text { sons } \\
3 \text { sons } \\
2 \text { sons } \\
3 \text { sons, } 1 \text { brother } \\
4 \text { sons }\end{array}$ \\
\hline
\end{tabular}

TABLE V.-Serum Creatine Kinase Activity in Women Known to be Heterozygous for the Gene for Mild Sex-linked Muscular Dystrophy

\begin{tabular}{|c|c|c|c|c|c|}
\hline \multirow{2}{*}{ Fammlies } & \multicolumn{4}{|c|}{$\begin{array}{l}\text { Serum Creatine Kinase Activity }(\mu \mathrm{M} \\
\left.\text { Creatine } / \mathrm{ml} \text {. Serum } / \mathrm{hr} \text {. at } 37^{\circ} \mathrm{C} .\right)\end{array}$} & \multirow{2}{*}{$\begin{array}{l}\text { Affected Relatives } \\
\text { of Heterozygous Women }\end{array}$} \\
\hline & Ist & 2nd & $3 \mathrm{rd}$ & Mean & \\
\hline L $\left\{\begin{array}{l}\mathbf{I}_{\mathbf{k}} \\
\mathbf{I}_{\mathrm{s}}\end{array}\right.$ & $\begin{array}{l}3 \cdot 4 \\
5 \cdot 3\end{array}$ & $\begin{array}{l}3 \cdot 9 \\
2 \cdot 4\end{array}$ & $\begin{array}{l}5 \cdot 3 \\
3 \cdot 7\end{array}$ & $\begin{array}{l}4 \cdot 20 \\
3 \cdot 80\end{array}$ & \} See pedigree $\mathrm{L}$ \\
\hline 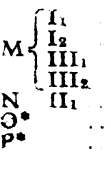 & $\begin{array}{r}1 \cdot 4 \\
3.7 \\
1.7 \\
10 \cdot 3 \\
2 \cdot 4 \\
1.4 \\
3 \cdot 2\end{array}$ & $\begin{array}{l}1 \cdot 5 \\
2 \cdot 8 \\
1 \cdot 2 \\
9 \cdot 0 \\
5 \cdot 6 \\
0 \cdot 8 \\
3 \cdot 1\end{array}$ & $\begin{array}{l}1 \cdot 4 \\
3 \cdot 1 \\
1 \cdot 7 \\
9 \cdot 2 \\
3 \cdot 1 \\
1 \cdot 4 \\
2 \cdot 6\end{array}$ & $\begin{array}{l}1.43 \\
3.20 \\
1.53 \\
9.50 \\
3.70 \\
1.20 \\
2.96\end{array}$ & $\begin{array}{l}\text { See pedigree } M \\
\text { See pedigree } N \\
2 \text { sons, three brothers } \\
1 \text { son, } 2 \text { brothers }\end{array}$ \\
\hline
\end{tabular}

SEVERE FORM

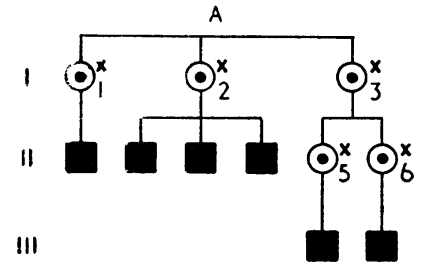

MILD FORM

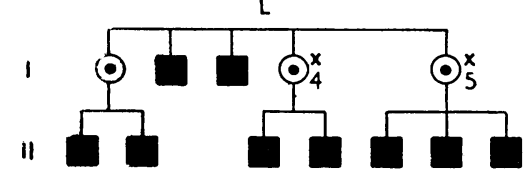

iil
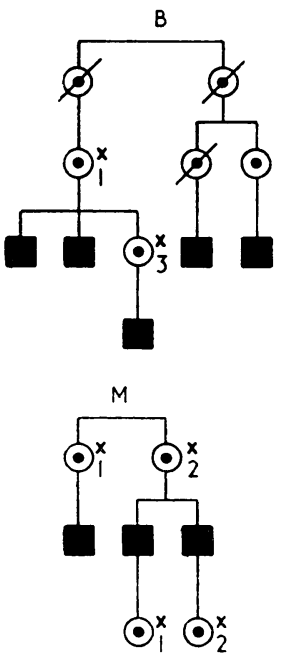

dystrophy are shown in Table $\mathrm{V}$ and Fig. 2, with corresponding genetic details in Table $\mathrm{V}$ and Fig. 3. The overall mean was 3.50 and standard deviation 2.51 ; using logarithms, the range was 0.79 to 10.59 units. The two girls (aged 9 and 6 years) had the highest (9.5 units) and the third lowest (1.5 units) levels respectively.

The findings in five women heterozygous for the gene for autosomal recessive muscular dystrophy (with childhood onset) are shown in Table VI and Fig. 2. The overall mean was 2.03 and standard deviation 0.85 ; using logarithms, the range was 0.92 to 3.20 units.

TABLE VI.-Serum Creatine Kinase Activity in Women Known to be Heterozygous for the Gene for Autosomal Recessive Muscular Dystrophy

\begin{tabular}{|c|c|c|c|c|c|c|}
\hline \multirow[t]{2}{*}{ Families } & \multicolumn{4}{|c|}{$\begin{array}{l}\text { Serum Creatine Kinase } \\
\text { Activity }(\mu \mathrm{M} \text { Creatine } / \mathrm{ml} \text {. } \\
\left.\text { Serum } / \text { hr. at } 37^{\circ} \mathrm{C} .\right)\end{array}$} & \multirow[t]{2}{*}{ Affected Relatives } & \multirow[t]{2}{*}{$\begin{array}{c}\text { Conjugal } \\
\text { Consanguinity }\end{array}$} \\
\hline & $1 \mathrm{st}$ & 2nd & $3 \mathrm{rd}$ & Mean & & \\
\hline Q & $1 \cdot 7$ & $1 \cdot 0$ & $4 \cdot 3$ & $2 \cdot 33$ & 1 son & 1st cousins once re- \\
\hline $\begin{array}{l}\mathrm{R} \\
\mathrm{S} \\
\mathrm{T}\end{array}$ & $\begin{array}{l}1 \cdot 4 \\
2 \cdot 8 \\
0.8\end{array}$ & $\begin{array}{l}0 \cdot 8 \\
2 \cdot 2 \\
1 \cdot 7\end{array}$ & $\begin{array}{l}1 \cdot 4 \\
2 \cdot 2 \\
1 \cdot 6\end{array}$ & $\begin{array}{l}1 \cdot 20 \\
2 \cdot 40 \\
1 \cdot 37\end{array}$ & $\begin{array}{l}1 \text { daughter } \\
2 \text { daughters, } 3 \text { sons } \\
\text { Dizygotic twin }\end{array}$ & $\begin{array}{l}\text { moved } \\
\text { 1st cousins } \\
\text { Nil } \\
\text { Nil }\end{array}$ \\
\hline U & $1 \cdot 2$ & $1 \cdot 8$ & 1.9 & 1.63 & $\begin{array}{l}\text { daughters } \\
1 \text { daughter }\end{array}$ & Nil \\
\hline
\end{tabular}

\section{Discussion}

Only one of the 21 control women had a mean enzyme level, on three specimens, of more than 2 units. Only one of 17 carriers of the gene for severe sex-linked muscular dystrophy had a mean level, on three specimens, of less than 2 units. Using the logarithms of the enzyme levels and assuming normal distributions, the level which discriminates best between the two groups is 1.92 units. This is 1.44 standard deviations from each of the two means of the logarithms of the levels, so that less than $10 \%$ of control women will be expected to have a level higher than 1.9 units, and less than $10 \%$ of carrier women will be expected to have a level lower than 1.9 units. Both means and standard deviations may alter somewhat as more controls and carriers are tested; but it is probable that the proportion of correct classification as carrier or non-carrier by creatine kinase levels on three separate specimens will remain of the order of $90 \%$. For work of this kind it is desirable that each laboratory should establish its own distributions for controls and carriers.

At a more sophisticated level the distributions may be used to help estimate the relative probability that a particular woman is or is not a heterozygote. For example, considering the case of a young woman with two affected brothers, the genetic probability is that she is equally likely to be, or not to be, a carrier. If her enzyme level is close to 1.9 units, this gives no additional information. If, however, her enzyme level is 1.5 units (logarithm 0.18), this, on present evidence, is lower than that expected in all but about $3 \%$ of carriers. In contrast, about 30\% of controls would be expected to have a level higher than this. Therefore a level of 1.5 units gives a relative 
probability of about 10 to 1 that the woman is not a heterozygote, and, combining the genetic and the biochemical information, the total relative probability is still about 10 to 1 that she is not a carrier. If such a young woman has a serum level of 2.5 units (logarithm 0.40) this is higher than that found in all but about $2 \%$ of controls, and about $20 \%$ of carriers have lower levels, so that the combined relative probability is about 10 to 1 that she is a heterozygote.

If the genetic probability had not been 1 to 1 but 3 to 1 against the woman being a heterozygote, then enzyme levels of 1.5 units and 2.5 units would give, respectively, combined relative probabilities of about 30 to 1 against and about 3 to 1 in favour of her being a heterozygote. A young woman taken at random from the population and with no relative with muscular dystrophy would have a genetic probability of only about 1 in 5,000 of being a carrier. So even if her enzyme level was 2.5 units, the total relative probability would still be about 500 to 1 against her being a carrier.

The number of women heterozygous for the genes for the mild sex-linked and autosomal recessive types who have been tested for creatine kinase levels is too small to establish reliable means and ranges. However, it is interesting that, though the mild sex-linked variety is clinically less severe than the autosomal recessive form, the enzyme levels of the carriers of the gene for the sex-linked form do not differ significantly from the levels in the carriers of the severe sex-linked form; while levels in the carriers of the gene for the autosomal form do not differ significantly from those in controls. This is intelligible on the Lyon hypothesis that, in women heterozygous for mutant genes on the X-chromosome, many cells will have as the active $\mathrm{X}$-chromosome the one which carries the mutant gene.

\section{Summary}

Serum creatine kinase levels, using the method of Hughes, were measured on three separate occasions on 21 control women, 17 women heterozygous for the gene for severe sex-linked muscular dystrophy, five women and two girls heterozygous for the gene for the mild sex-linked form, and five women heterozygous for the gene for the autosomal recessive form. The mean level in the control women was 1.31 units $(\mu \mathrm{M}$ creatine per ml. serum per hour at $37^{\circ}$ C.) and for the women heterozygous for the gene for severe sex-linked muscular dystrophy 4.02 units.

Using the logarithms of the enzyme levels to give more normal distributions the range for controls was 0.70 to 2.27 units and the range for heterozygotes for the gene for the sexlinked form was 1.50 to 8.93 units. About $90 \%$ of controls will have a mean level below 1.9 units and about $90 \%$ of heterozygotes will have a mean level above 1.9 units. The distribution of the logarithms of the enzyme levels may be used in combination with the available genetic information to estimate the relative probability that a woman is or is not a heterozygote. For example, assuming normal distributions of the logarithms of the levels, below a level of 1.5 units the relative probability, from the enzyme level, was more than 10 to 1 that the woman was not a heterozygote; above 2.5 units it was more than 10 to 1 that the woman was a heterozygote.

In the small series of women heterozygous for the mild sexlinked and autosomal recessive forms the creatine kinase levels in the former did not differ significantly from those in the severe sex-linked form, and creatine kinase levels in the latter did not differ significantly from those in the controls.

We are grateful to the members of the families of patients with muscular dystrophy, and to the controls, for providing repeated specimens of blood. We thank Dr. B. P. Hughes for demonstrating his method of creatine kinase estimation; Dr. H. Johnson and Dr. H. Blyth for sending samples of serum from Oxford and Leeds; Dr. P. D. Griffiths for telling us of unpublished work on the effects of exercise ; and Mrs. J. Shepherd for valuable technical assistance. We are particularly grateful to Dr. B. E. Clayton and Dr. J. A. F. Roberts, F.R.S., for advice and encouragement. One of us (K. M. W.) is indebted to the joint Research Board of the Institute of Child Health and the Hospital for Sick Children for financial help.

\section{REFERENCES}

Aebi, U., Richterich, R., Colombo, J. P., and Rossi, E. (1961-2). Enzym. biol. clin. (Basel), 1, 61 .

Blyth, H., and Pugh, R. (1959). Ann. hum. Genet., 23, 127.

Chung, C. S., Morton, N. E., and Peters, H. A. (1960). Amer. F. hum.

Clayton, B. E., Wilson, K. M., and Carter, C. O. (1963). Arch. Dis. Childh., 38, 208.

Dreyfus, J. C., and Schapira, G. (1961). Rev. franç. Etud. clin. biol., 6, 700 .

Griffiths, P. D. (1964). F. clin. Path., 17, 56.

Hughes, B. P. (1962a). Brit. med. F., 2, 963

(196.2b). Clin. chim. Acta, 7, 597.

Leyburn, P., Thomson, W. H. S., and Walton, J. N. (1961). Ann. hum. Genet., 25, 41.

Pearce, J. M. S., Pennington, R. J., and Walton, J. N. (1964a). F. Neurol. Neurosurg. Psychiat., $27,1$.

Neurosurg. Psychiat., 27, 1. 27, 181.

Richterich, R., Rosin, S., Aebi, U., and Rossi, E. (1963). Amer. 7. hum. Genet., 15, 133.

Schapira, F., Dreyfus, J. C., Schapira, G., and Demos J. (1960). Rev. franç. Etud. clin. biol., 5, 990.

\title{
Double-blind Trial of Bismuth Aluminate and Magnesium Trisilicate in Peptic Ulceration with Simultaneous Gastric Analysis
}

\author{
S. G. FLAVELL MATTS,*† M.B., CH.в., M.R.C.P.ED.; C. H. J. SWAN,* M.B., CH.B.; J. KELLEHER,* M.SC., A.R.I.C.
}

Brit. med. F., 1965, 1, 753-756

There is no general agreement on the best form of medical treatment for peptic ulceration, although most people are prepared to consider the medical management of gastric and duodenal ulcers together as "peptic ulcer" in spite of the fact that their aetiology may be somewhat different (Dragstedt, 1962 ; Avery Jones, 1964). It is accepted that the actual ulcer is caused by digestion of the mucosa by pepsin and hydrochloric acid, but the factors that allow this to happen are obscure. Excessive secretion of hydrochloric acid has been put forward as a likely cause, and it is partly on this basis that antacids are given in treatment. Other workers favour the idea that decreased tissue resistance is the basic cause of peptic ulcer and postulate many underlying factors influencing the decrease in resistance. Additional causes that have been given include excessive pepsin production, stress, hormonal dysfunction, and regurgitation of duodenal contents into the stomach (Spira, 1956, 1964 ; Sun, 1962 ; Dragstedt, 1962 ; Lancet, 1962).

In spite of this difference of opinion on aetiology, the most widely recommended form of therapy consists of modification

* The Royal Hospital, Wolverhampton.

† Present address: The Royal Marsden Hospital, London. 